\title{
Communication Boot Camp: Discover the Speaker in You!
}

\author{
Zuraidah Binti Ali (corresponding author) \\ Universiti Tenaga Nasional \\ E-mail: Zue@uniten.edu.my \\ Noor Hafiza Binti Nor Azmi \\ Universiti Tenaga Nasional \\ Alicia a/p Phillip \\ Universiti Tenaga Nasional \\ Mohd Zin bin Mokhtar \\ Universiti Tenaga Nasional
}

\author{
Doi:10.7575/aiac.alls.v.4n.2p.141 \\ URL: http://dx.doi.org/10.7575/aiac.alls.v.4n.2p.141
}

Received: 04/04/2013

Accepted: 04/06/2013

\begin{abstract}
Learning can take place almost anywhere, and this is especially true for our undergraduates who wish to become public speakers. Besides university course and public speaking workshops on campus grounds, undergraduates are now looking for a different learning environment - communication boot camps!! This study presents a compilation of learners' experience, fun-filled activities, insightful feedback and memorable boot camp moments as captured in camp photos and feedback surveys. It involves a total of thirty seven undergraduates who enrolled in a Communication Boot Camp at Janda Baik, Pahang. Results show that Communication Boot Camp is a successful strategy to groom public speakers with a positive correlation between camp success and camp objectives, particularly in reducing shyness, motivating participants to become public speakers and discovering their talent and skills. In short, the study adds to the promise of zest and delight in public speaking.
\end{abstract}

Keywords: Communication Boot Camp, public speaking, undergraduates.

\section{Introduction}

Communication is an important skill that helps improve relationship, avoid misunderstanding and convey clear messages. It is also a skill that is used to influence people's feelings, thought and action. Muthiah (2012) informs that communication involves at least two persons: the sender and the receiver. To achieve successful communication, the receiver must be able to understand the intended message conveyed by the speaker.

For undergraduates, communication skill is not limited to the mere ability to interact in a two-way communication. Instead, university education is synonymous with public speaking and presentations. Besides project presentations embedded in the course, university activities prepares undergraduates with rich experience like competitions which provides opportunities for confident and eloquent speakers.

Hence, communication skills bears more significance and rewarding results in the form of influence (Zuraidah, 2013), success in selection interviews, and the employability. To illustrate, a research conducted by Quah (2009) shows that among 12 generic skills and traits measured for entry level job seekers, communication skills and confidence/ positive image topped the list.

Therefore this paper aims to suggest the method and ways to improve communication skills and further develop the skill to produce competent and effective speakers among undergraduates.

\section{Literature Review}

Languages are seen as a vital tool in communication. This is supported by Adler and Rodman (2003) who state that languages are essential to communication. One of the prominent languages that are used worldwide is the English Language. English Language is widely known as the lingua franca of the world. It is able to help communication between countries (Muthiah, 2012).

In the Malaysian context, English language is the second language of the country. It is widely used in every industry in Malaysia especially in the education industry. Therefore, it is vital for learners of the second language in Malaysia to be 
able to communicate effectively in English. In most situations, reluctant learners would need more supportive learning environment (Zuraidah, 2007) which includes learning outside the classroom.

However, Malaysian learners often lack the motivation to learn and use English (Gaudart, 1992; Sharifah Sheha, 2005; Zuraidah, 2007). This happens when they can be understood in their mother tongue. Another evidence of reticence is prevalent due to lack of exposure (Jamali Ismail, 1991). This predicament is a worrying factor to the country because poor command of the English language would lead to low employability.

A common reason that contributes to poor command of English among Malaysian learners includes lack of competence in communication, thus unwilling to communicate. Dornyei (2003) states that learners must be both competent and willing to communicate in order to use the second language. Hymes (1971) indicates that the ability to know to communicate in the right time and manner is defined as communicative competence.

\section{Research Methodology}

This research was carried out using the survey methodology and document analysis. A structured questionnaire was developed based on a review of existing literature in which respondents were asked as set of five-point Likert scale questions pertaining to knowledge enhancement, transformation and overall success of the public speaking intervention program: Communication Boot Camp: Discover the Speaker in YOU!!

\subsection{Participants}

Participants consisted of 37 undergraduates at the College of Foundation and General Studies, Universiti Tenaga Nasional (UNITEN). It is a semi-private university that uses English as its medium of instruction.

\subsection{Procedures}

Participants were recruited via campus advertisements (posters, facebook, email from the college deputy dean, in-class instructor announcements). Students signed up for the Communication Boot Camp aimed at discovering the 'speaker' within them. Registered participants were then invited to attend a briefing held at the college and complete a survey on public speaking background knowledge and experience, as well as the Personal Report of Public Speaking Anxiety (PRPSA). The result of the PRPSA administration will not be discussed in this paper.

The briefing was led by the first author who described the objective of the Communication Boot Camp which is to transform the participants into public speakers. Later, the participants were introduced to the main concepts of the camp:
i. drama techniques
ii. group discussions
iii. singing and speech competition
iv. debate and argumentative reasoning
v. impromptu and extemporaneous speech

In order to invite anticipation and excitement among the participants, the program leaflet was also distributed together with the safety list. The Communication Boot Camp relies on delivery of eight modules as follows:

Table 1. Communication Boot Camp Module

\begin{tabular}{c}
\hline MODULE 1: COMMUNICATION SKILLS \\
\hline MODULE 2: THE FAST TRACK \\
\hline MODULE 3: THE WORLD'S A STAGE \\
\hline MODULE 4: BATTLE OF WITS \\
\hline MODULE 5: EXPLORACE \\
\hline MODULE 6: FROM 'PAPA' TO PRADA \\
MODULE 7: MY CUTTING EDGE \\
\hline MODULE 8: FINALE
\end{tabular}

Next, students were encouraged to submit their names to participate in a one-act play performance, and the singing and speech competition. Since the students registered with the intervention to develop their public speaking skills, the first author didn't have to wait long for them to sign up for all the categories. Finally, the students were instructed to prepare themselves physically and mentally for a three-day outside-class experience on public speaking. 
A self-designed survey form was distributed to all participants on-site immediately after they completed the eight modules for the Communication Boot Camp. The survey has a total of eleven items measuring three aspects: knowledge enhancement aspect, transformation aspect, overall success. Besides, the survey includes one section for qualitative feedback. In this current study, the survey yielded alpha reliability of .85 .

\section{Research Findings and Discussion}

\subsection{Demography}

The present study was conducted on a total of 37 undergraduates at the College of Foundation and General Studies, Universiti Tenaga Nasional. The respondents comprised male and female undergraduates from two majors namely Engineering and Information Technology.

\subsection{Overall Impact on Respondents' Public Speaking Experience}

Results indicate that Communication Boot Camp is a successful strategy to groom public speakers. Besides fun learning experience, results predict that communication boot camp makes participants less shy to appear on stage and boosts their confidence and interest in becoming a public speaker.

\subsubsection{Knowledge Enhancement}

Table 2 below indicates the overall mean scores of respondent views and perception toward the impact of the intervention program. A majority of respondents agreed that they have realized the importance of public speaking skills for undergraduates after completing the eight modules (highest overall score of 4.65). The findings also indicate that the camp experience has motivated them to develop their public speaking skills (overall mean score $=4.54$ ) with a majority aspiring to become public speakers (overall score $=4.38$ ).

Also, the knowledge enhancement factor embedded in the camp module has been successful in imparting public speaking skills among the participants and providing them with ways and means to improve their abilities (overall mean score $=$ 4.41).

Table 2. Knowledge Enhancement

\begin{tabular}{llc}
\hline \multicolumn{2}{c}{ Item } & Overall mean \\
\hline 5 & I want to develop my public speaking skill. & 4.54 \\
\hline 6 & I wish to become a public speaker. & 4.38 \\
\hline 7 & I realize that public speaking skills is important for undergraduates. & 4.65 \\
\hline 8 & I know how to develop my public speaking skills. & 4.41 \\
\hline & Indicators: $1=S D$ & $2=D$
\end{tabular}

\subsubsection{Transformation Aspect}

Table 3 shows the impact of the Communication Boot Camp in transforming the participants into public speakers. From the aspect of transformation, the majority of respondents think that their engagement in the Communication Boot Camp has increased their willingness to speak in front of an audience (highest overall score of 4.49).

Willingness to speak is also associated with self-confidence particularly in expressing their opinion to others (overall score $=4.46$ ) and reduced level of shyness to appear on stage (overall score $=4.41$ ). Most respondents expressed willingness to participate in public speaking competitions (overall mean $=4.00$ ).

Table 3. Transformation Aspect

\begin{tabular}{|c|c|c|}
\hline & Item & Overall mean \\
\hline 1 & I am willing to speak in front of an audience. & 4.49 \\
\hline 2 & I am more confident to express my opinion to others. & 4.46 \\
\hline 3 & I will not be so shy to appear on stage. & 4.41 \\
\hline 4 & I will participate in public speaking competitions. & 4.00 \\
\hline
\end{tabular}

\subsubsection{Camp Overall Success}

Table 4 below shows the respondents' overall impression on the effectiveness of Communication Boot Camp as an intervention program to develop public speakers among undergraduates. Based on the findings, majority of the respondents claimed that they enjoyed themselves during the camp (highest overall mean score $=4.76$ ) and that it was a huge success (overall mean score $=4.62$ ). 


\begin{tabular}{|c|c|c|}
\hline & Item & Overall Mean \\
\hline 9 & I think I have discovered the public speaker in ME!! & 4.35 \\
\hline 10 & I enjoyed myself during the camp. & 4.76 \\
\hline 11 & I think the camp is SUCCESSful!! & 4.62 \\
\hline
\end{tabular}

Most importantly for this study, respondents also acknowledged that the camp has accomplished its main objective to allow participants to discover the 'speaker' in themselves. These findings support past studies implicating that out-of-class learning environment produces enjoyment, effectiveness and success in delivering content and delivery. For instance, Wan Idros Wan Sulaiman et al. (2010) discovered that out-of-class learning environment enhances learning satisfaction, concentration and focus. In their study, learners "preferred to learn in a relaxed and friendly environment".

\subsection{Correlations between Success Factor and other Learning Aspects}

A Pearson product-moment correlation coefficient was computed to assess the relationship between item 11 "I think the camp is successful" with the rest of the items in the questionnaire. Based on Cohen (1998), results indicate a positive moderate correlation between item 11 (Successful Rate ) and 5 other items (not shy, want to become a public speaker, know-how, discover, and enjoy) as in Table below:

Table 5: Correlation between Success factor and other Learning Aspects

\begin{tabular}{llccccc}
\hline & & $\begin{array}{c}\text { Not } \\
\text { Shy }\end{array}$ & $\begin{array}{c}\text { Public } \\
\text { Speaker }\end{array}$ & $\begin{array}{c}\text { Know } \\
\text { how }\end{array}$ & Discover & $\begin{array}{c}\text { Enjoy } \\
\text { Myself }\end{array}$ \\
\hline SuccessRate & $\begin{array}{l}\text { Pearson } \\
\text { Correlation }\end{array}$ & $.410^{*}$ & $.395^{*}$ & $.480^{* *}$ & $.350^{*}$ & $.337^{*}$ \\
\cline { 2 - 7 } & Sig. (2-tailed) & .012 & .016 & .003 & .034 & .041 \\
\cline { 2 - 7 } & $\mathrm{N}$ & 37 & 37 & 37 & 37 & 37 \\
\hline
\end{tabular}

This research shows a moderate positive correlation between successful rate of this camp with five factors: not shy to appear on stage $(r=0.410, n=37, p=0.12)$; willing to develop public speaking skill $(r=0.395, n=37, p=0.16)$, know how to develop public speaking skill $(r=0.480, n=37, p=0.03)$, discover the public speaker in themselves $(r=0.350$, $\mathrm{n}=37, \mathrm{p}=0.034)$ and enjoy during the $\operatorname{camp}(\mathrm{r}=0.337, \mathrm{n}=37, \mathrm{p}=0.41)$.

\subsection{Participants' Feedback in Social Media}

Another form of data analysis utilized in this study is document analysis. Results indicate participants showed positive feedback on the intervention program. The following screenshots from facebook illustrate this result. In both exhibits, participants were excited about the experience joining the camp and hoped that it will be organized again.

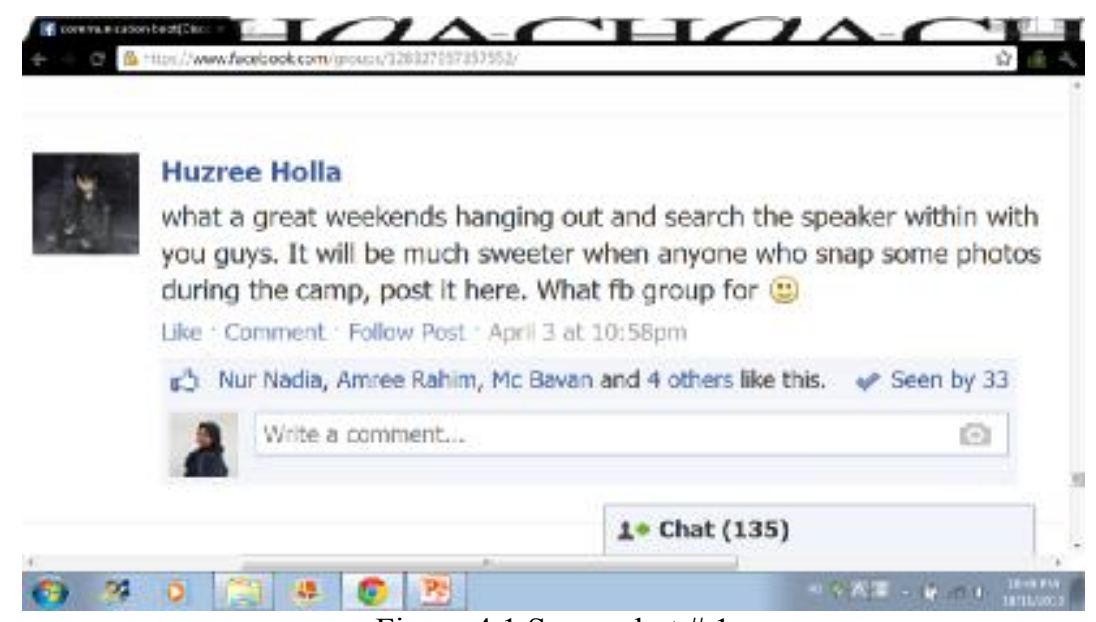

Figure 4.1 Screenshot \# 1 


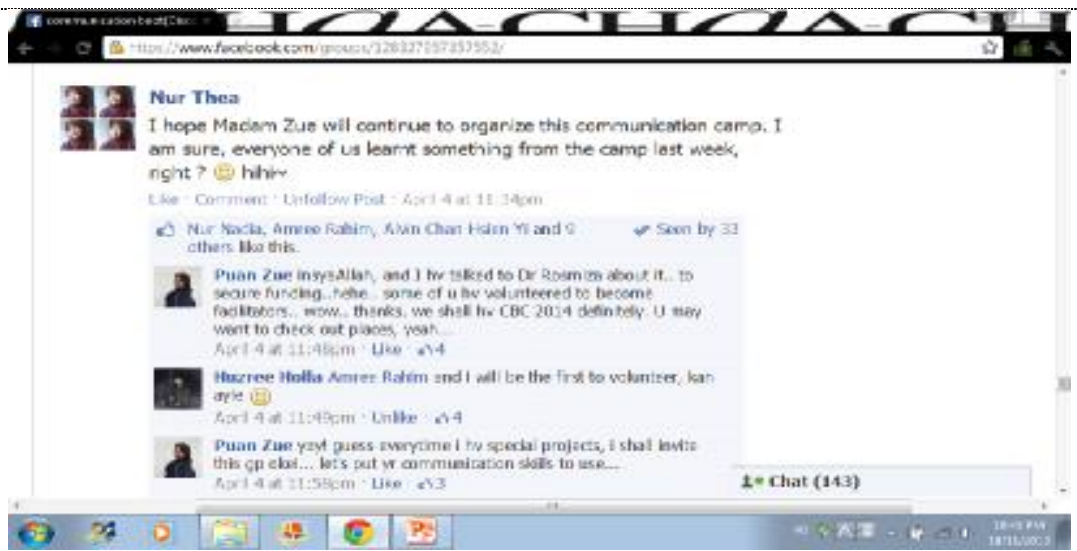

Figure 4.2 Screenshot \#2

The first author also wrote two articles on the Communication Boot Camp for nationwide circulation. Figure 4.3 below shows the publications in Utusan Malaysia (Gerbang Akademik).

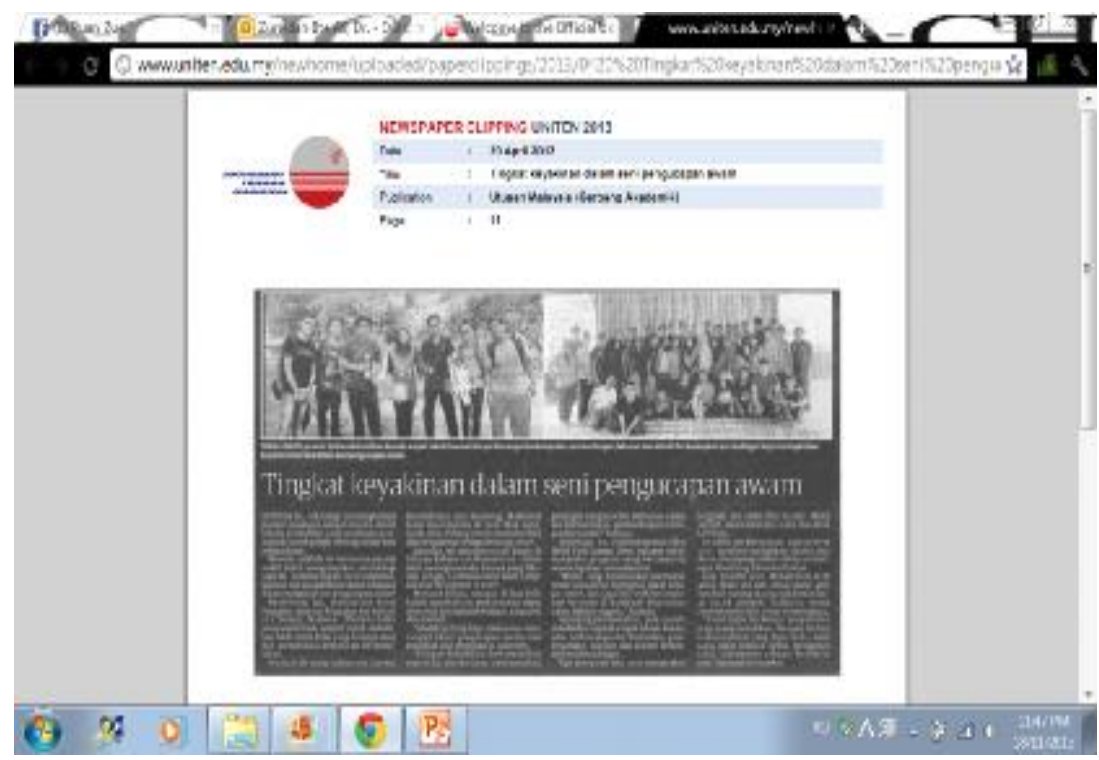

Figure 4.3 Communication Boot Camp in Berita Harian

Based on the analysis on social media, it was discovered that the publication of both news articles have also created impact on the camp participants. Figure 4.4 below shows that one of the participants posted his excitement about the publication on Twitter. This indicates the participant is proud of his involvement in the camp and that the experience was captured in the news bulletin.

Figure 4.5 is a screenshot on Facebook showing the parent to one of the camp particpants uploading the publication on her facebook wall. From this exhibit, it can be deduced that parents are also supportive of their children's involvement in the Communication Boot Camp.

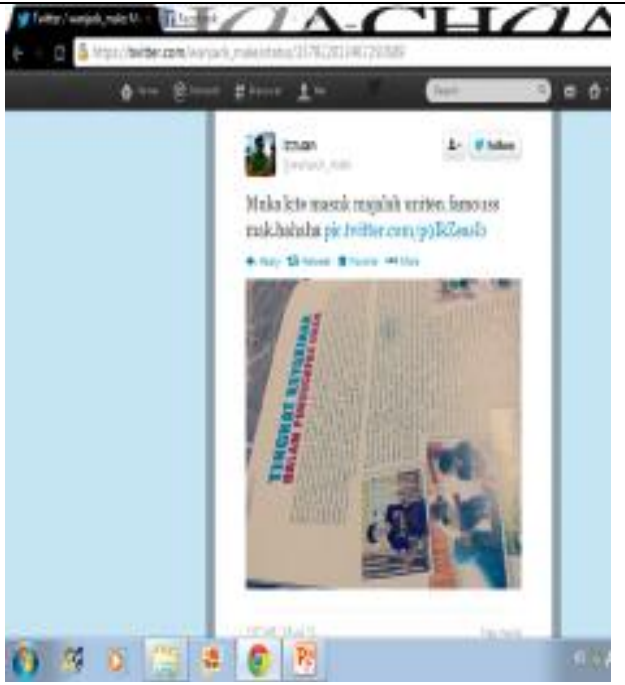

Figure 4.4 Screenshot \#3

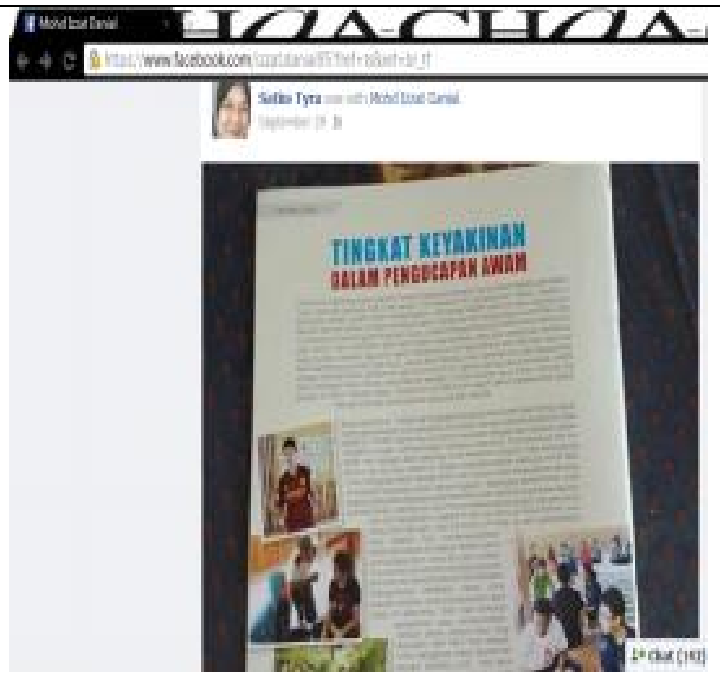

Figure 4.5 Screenshot \#4 


\section{Conclusion}

The results of this study prove that Communication Boot Camp is an effective strategy to develop public speakers among undergraduates. The module provides a learning environment outside the classroom which cultivates interest in group communication and public speaking. Besides, the camping approach blends academic objectives with active and fun learning experience that increases self-confidence and result in some transformation aspects.

\section{References}

Adler,R.B., and Rodman,G. (2003). Understanding Human Communication (8ed.). New York: Oxford University Press

Do“ rnyei, Z. (2003). Attitudes, orientations, and motivations in language learning: Advances in theory, research, and applications. Language Learning, 5(1), 3-32.

Gaudart, H. (1992). Persuading students to speak English. In Wijasuria, B. and Gaudart, H. (eds.), Teaching and Learning English in Challenging Situations. Proceedings for the first Malaysian English Language Teaching association International Conference.

Hymes, D.H (ed) (1971). Pidginization and Creolization of Languages. Cambridge: Cambridge University Press.

Jamali, I. (1991). Learning English in a non-supportive environment: The problem in Malaysian schools. In Wijasuria, B. and Gaudart, H. (eds.), Teaching and Learning English in Challenging Situations. Proceedings for the first Malaysian English Language Teaching association International Conference.

Muthiah.K. (2012). Global Importance of Communication Skills. .International Journal of Applied Research and Studies, $1(2), 1-6$.

Yeap.E.E.L (2012). Malaysian Secondary School Student's Willingness to Communicate in English (Master Dissertation ) Serdang: Universiti Putra Malaysia

Wan I.W., Maizatul Haizan, M., \& Arina A.A. (2011). Learning outside the classroom: Effects on student concentration and interest. Procedia Social and Behavioral Sciences, 18, 12-17.

Zuraidah, A. (2007). Willing Learners yet Unwilling Speakers in ESL Classrooms. Asian Journal of University Education, 3(2), 57-74.

Zuraidah. A. (2013) Influence Strategies in Consensual Small Group Decision Making among Malaysian Undergraduates (PhD Dissertation) Bangi: Universiti Kebangsaan Malaysia 